\title{
Fonologia histórica do latim ao português (sécs. I-III d.C.): vocalismo, aquisição e epistemologia
}

\author{
Wagner Argolo Nobre \\ União Metropolitana de Educação e Cultura (Brasil) \\ wagner.argolo@gmail.com
}

Recibido o 18/09/2017

Aceptado o 14/02/2018

\begin{abstract}
Historical phonology from Latin to Portuguese in the $1^{\text {st }} 3^{\text {rd }}$ centuries AD: vowel system, language acquisition and epistemology
\end{abstract}

\begin{abstract}
Resumo
Neste artigo, tentamos esboçar uma reanálise de como se perdeu o traço de quantidade das vogais latinas, levantando as seguintes hipóteses que a guiaram: i) a perda da quantidade vocálica teve início já durante as Guerras Púnicas; ii) tal mudança teve como uma de suas fontes irradiadoras o Norte e parte do Sudeste da Península lbérica; iii) tal mudança foi o resultado de processos de aquisição do latim como segunda língua, por povos conquistados, e foi transmitida às gerações seguintes, completando-se. Esta última hipótese é a principal e está atrelada à visão de complementaridade entre os estudos da Sociolinguística e do Gerativismo, denominada, por Tarallo (1987), seu primeiro teorizador, de Sociolinguística Paramétrica. Para fazer esta atrelagem, procuramos estender sua teorização ao nível do objeto, de modo a que os processos sócio-históricos que envolveram a expansão do latim pudessem ser conjugados com o paradigma gerativista de aquisição da linguagem - o que inclui a assunção da existência prévia do componente biológico-cerebral, que disponibiliza uma Gramática Universal para o uso inato da criança, quando começa a adquirir uma língua. Portanto, trata-se de um trabalho situado, simultaneamente, na linguística teórica e na linguística românica.
\end{abstract}

\section{Palabras chave}

Linguística teórica; linguística românica; mudança fonológica; latim; português

\section{Sumario}

1. Introdução. 2. A perda da quantidade vocálica e suas importantes repercussões. 3. A Sociolinguística Paramétrica: uma reflexão ao nível do objeto teórico. 3.1. Aquisição da linguagem. 3.2. Fonética e Fonologia. 4. Estudos anteriores sobre a perda da quantidade vocálica. 5. Conclusão.
Abstract outlines a proposed reanalysis of how the feature of vowel length was lost in Latin, assuming the following hypotheses: i) the loss of vowel length began during the Punic Wars; ii) this change had as one of its radiating sources the North and part of the Southeast of the Iberian Peninsula; iii) this change was the result of processes of acquisition of Latin as a second language by conquered peoples and was transmitted to succeeding generations who carried it to completion. This last hypothesis is the main focus. The approach used is linked to the view of complementarity between the study of Sociolinguistics and Generativism which its first theoretical proponent, Tarallo (1987), calls Parametric Sociolinguistics. This article, extending the theory to the level of the object, examines the socio-historical processes involved in the expansion of Latin from the perspective of the generative paradigm of language acquisition. This paradigm assumes the prior existence of a biological-cerebral component which provides an innate Universal Grammar by means of which a child begins to acquire a language. The study is therefore relevant to both theoretical linguistics and Romance linguistics.

Keywords

Theoretical linguistics; Romance linguistics; phonological change; Latin; Portuguese

Contents

1. Introduction. 2. The loss of vowel quantity and its repercussions. 3. Parametric Sociolinguistics: a reflection at the level of the theoretical object. 3.1. Language acquisition. 3.2. Phonetics and Phonology. 4. Previous studies on the loss of vowel quantity. 5. Conclusion. 


\section{INTRODUÇÃo}

Quando nos debruçamos sobre trabalhos que abordam as mudanças no subsistema fonológico do latim para o subsistema fonológico do romance galego-português - e aqui nos referimos à modalidade oral dessas línguas, já que é nela que as mudanças linguísticas sempre têm início -, alguns aspectos são consenso entre estudiosos do assunto, como, por exemplo, a perda da distinção de quantidade de suas vogais. A distinção de quantidade era um mecanismo importante, pois possibilitava ao latim, mesmo possuindo apenas cinco vogais timbricamente distintas, apresentar a característica funcional de realizar dez vogais, já que, para cada timbre de vogal, havia uma realização breve e uma realização longa.

Desse modo, tal perda teria dado lugar a uma distinção vocálica apenas tímbrica, fato que, se, por um lado, diminuiu a amplitude funcional das vogais latinas, por outro, aumentou, em termos tímbricos - e consequentemente em termos orgânicos -, seu inventário vocálico, que passou, assim, a ser composto de sete fonemas, cada um com seu timbre característico.

Neste artigo, temos, como problema central, que atuará como fio condutor ao longo de todas as considerações feitas daqui por diante, a tentativa de apresentar uma reanálise da explicação de quando, onde e como se deu o processo de perda desse traço fonológico, fato que resultou em uma série de mudanças encadeadas que seriam algumas das principais responsáveis pela configuração estrutural que veio a caracterizar, em última instância, a língua portuguesa. Entretanto, a importância do processo, em si, tem como corolário a concentração de nossas reflexões no como, o que será perceptível ao longo deste texto.

Desse modo, no intuito de estabelecer nosso recorte temporal para a investigação do problema, adotamos, como ponto de partida, as informações que Silva Neto (1957a) e Castro (1991) fornecem a esse respeito, ou seja, o século I d.C. como terminus a quo do processo de perda da distinção fonológica de quantidade e o século III d.C. como terminus ad quem desse processo de mudança.

Vejamos o que diz, Silva Neto (1957a: 176-177), depois de ressalvar que, quando um fenômeno de mudança aparece na escrita, "[...] é porque já existia há muito tempo, em círculos reduzidos ou socialmente desprestigiados": "[...] pode indicar-se o IIIo século d.C. como o marco da perda da oposição quantitativa, perda que se estendeu a toda a România, mas que provavelmente se deu mais cedo nas regiões a princípio mais aloglotas".

E, agora, Castro (1991: 115), ao afirmar que "[...] a perda da distinção de quantidade estava generalizada no século III, tendo-se esboçado a partir do século I da nossa era".

No que se refere ao recorte geográfico, basear-nos-emos também nesses autores, sendo que o primeiro refere-se claramente à África como o locus onde o fenômeno teria se iniciado e a partir de onde teria se difundido para o restante do mundo romano, ao afirmar que "De fato, vêm-nos da África os primeiros indícios da perda da quantidade, o que não deve surpreender, já que é próprio da ação dos aloglotas apressar a deriva imanente à língua" (Silva Neto 1957a: 177, grifo do original), enquanto o segundo refere-se a Pompeia, cidade da Campânia romana, como o locus de início e de irradiação de tal fenômeno, ao afirmar que "Os graffiti de Pompeia exibem já alguns casos de confusão entre [ī] e [ē], ou entre [ō] e [ŭ] [...]" (Castro 1991: 115, grifo do original).

Não se deve estranhar o fato de, na transcrição fonética apresentada por Castro (1991), ler$\operatorname{mos}[\bar{i}]$ e [ē] e [ō] e [ŭ], e não [ī] e [ī] e [ŭ] e [ū]. Isto porque, apesar de, fonologicamente, as vogais em questão serem /ĩ/ e /ī/ e /ŭ/ e /ū/, foneticamente, no momento da articulação, o /î/, sistematicamente, sofria um ligeiro abaixamento, sendo pronunciado com o timbre de [ē], o mesmo ocorrendo com o /ŭ/, que, sistematicamente, também sofria um ligeiro abaixamento, sendo pronunciado com o timbre de [ō].

Aliás, é justamente dessa fusão articulatória entre [̄̄] e [ē] e [ō] e [ŭ] - no âmbito da fonética - que, depois de generalizada, e não mais percebida pelos falantes do mundo romano, se dará a neutralização entre os fonemas /î/ e /ī/ e /ŭ/ e /ū/ - no âmbito da fonologia, portanto. A perda da percepção do traço de quantidade, primeiro, nos fones, e, depois, nos fonemas referidos, certamente atingiu a percepção da distinção de quantidade entre [ă] e [ā], resultando também na 
neutralização fonêmica entre /ă/ e /ā/, concretizando a passagem do subsistema fonológico do latim falado imperial para o subsistema fonológico do latim falado tardio, que viria a se manter, sem alterações, no romance galego-português e, posteriormente, no português, como se pode ver no seguinte esquema, extraído de Castro (1991: 113):

\begin{tabular}{|c|c|c|c|c|c|c|c|c|c|c|}
\hline Latim & $/ \overline{1} /$ & $/ \overline{\mathbf{1}} /$ & $/ \overline{\mathrm{e}} /$ & /ë/ & $/ \overline{\mathrm{a}} /$ & $/ a ̆ /$ & $/ \breve{o} /$ & $/ \overline{0} /$ & $/ \breve{\mathrm{u}} /$ & $/ \overline{\mathrm{u}} /$ \\
\hline Português & $/ \mathrm{i} /$ & \multicolumn{2}{|c|}{$/ \mathrm{e} /$} & $\mid \varepsilon /$ & \multicolumn{2}{|c|}{$/ \mathrm{a} /$} & $/ 0 /$ & \multicolumn{2}{|c|}{$10 /$} & $/ \mathrm{u} /$ \\
\hline
\end{tabular}

Quadro 1. Comparação entre o elenco de vogais do latim e o elenco de vogais do português

Entretanto, no que se refere à explicação de como se deu essa mudança linguística, a descrição do processo articulatório que teria se generalizado, acabando por atingir o subsistema fonológico, modificando-o sensivelmente, não dá conta, a nosso ver, de toda sua amplitude, que envolve, necessariamente, uma conjugação dos referidos processos intralinguísticos com processos sociais.

Desse modo, as opiniões divergem, variando entre [i] a tradicional abordagem das influências de substrato, devidas a longos processos de bilinguismo no seio dos povos conquistados pelos romanos (Silva Neto 1957b; Ilari 1998), [ii] a recente abordagem de explicação dessa mudança como parte de processos de pidginização e crioulização do latim, ao longo de séculos de sua imposição sobre esses povos (Barros Ferreira 1992), e [iii] a relativamente recente - e inovadora para o momento em que foi publicada - abordagem dessa mudança como ocorrida na aquisição do latim como segunda língua, pelos adultos subjugados nas conquistas romanas, sendo nativizada - e, consequentemente, implementada - pelas gerações seguintes, compostas pelos filhos desses adultos, posteriormente presente, também, em Silva Neto (1957a).

Por se tratar de um tema imerso num campo de estudos com longa tradição, que se estende desde a segunda metade do século XIX, com os primeiros estudos do filólogo alemão Diez (17941876), passando pelos trabalhos de Schuchardt (1842-1927), Meyer-Lübke' (1861-1936), Meillet (1866-1936), Väänänen (1905-1997) - divulgados ainda na primeira metade do século XX -, até os dias atuais, com os trabalhos de Silva Neto (1917-1960), Castro (1945-) e Teyssier (1915-2002), para citar apenas alguns - divulgados na segunda metade do século XX -, seria uma tarefa extremamente difícil tentar propor hipóteses completamente originais a esse respeito.

Por isso, não é nossa intenção, neste artigo, alcançar este intento, mas, sim, trazer elementos novos, hauridos dos avanços da linguística contemporânea, para tentar aprimorar as hipóteses já existentes sobre seu tema-objeto.

Vamos, então, às hipóteses propriamente ditas, que serão introduzidas em forma de respostas às perguntas que as precedem:

a. Como se considera o século I d.C. como o terminus a quo da perda do traço fonológico de quantidade vocálica do latim falado, se, como sabemos, quando uma mudança é detectada na escrita, isto significa que já se implementou na fala muito tempo antes?

(a') Primeira hipótese: a perda do traço de quantidade das vogais latinas começa a ocorrer ainda no período republicano de Roma (509-27 a.C.), porque é nele que tem início a expansão dos romanos para fora da Península Itálica, seguida do domínio de toda a margem norte do Mar Mediterrâneo e, depois, da margem sul. Tal expansão teve como principal veículo as três Guerras Púnicas (264-146 a.C.), travadas com Cartago (atual Tunísia, no Norte da África), durante as quais os romanos fazem suas primeiras conquistas fora da Península Itálica, a exemplo da Bética (correspondente à atual Andaluzia, na Es-

\footnotetext{
${ }^{1}$ Por limitações de língua, já que foram escritos em alemão, nosso acesso ao conteúdo dos trabalhos de Diez, Schuchardt e Meyer-Lübke foi indireto, tido através, principalmente, da História do latim vulgar (1957b), de Silva Neto.
} 
panha) e da Tarraconense (correspondente às regiões de Castela, Múrcia e Valência, também na Espanha), na Península Ibérica, conquistadas entre 197 e 183 a.C. O avanço dos romanos sobre essas novas regiões significava o avanço do latim sobre povos aloglotas, fato que, geralmente, tem consequências não apenas sobre o subsistema fonológico de uma língua, mas sobre o sistema de uma língua como um todo.

b. Como se consideram apenas o Norte da África e Pompeia como locais onde se iniciou o processo de perda do traço de quantidade das vogais do latim falado, se estes não foram os únicos locais, fora de Roma, englobados pela primeira grande expansão romana, durante as Guerras Púnicas?

(b') Segunda hipótese: os locais onde teve início o processo de perda de quantidade das vogais do latim falado não foram apenas o Norte da África e Pompeia, mas, também, a Península Ibérica, conquistada parcialmente entre 197 e 183 a.C. Mais especificamente, tal perda teria se iniciado, em paralelo com as duas regiões referidas, também na província Tarraconense, que se espraiava por sobre o Norte e parte do Sudeste da Península Ibérica, por ser uma vasta área que, depois de romanizada, apresentou um latim menos conservador do que a Província da Bética - isolada ao Sul -, já que a Tarraconense, por estar no liame da Península Ibérica com o interior do continente europeu, era uma região de trânsito e contato de povos distintos - que exerciam, por exemplo, funções comerciais e militares -, fato que facilitava inovações no latim falado, o que pode ser aplicado à perda de sua quantidade vocálica.

c. É possível conceber a formação do romance galego-português com base, apenas, na hipótese da transferência de características dos substratos ou de processos de pidginização e crioulização do latim, durante o contato resultante de sua imposição sobre as línguas autóctones das regiões fora da Península Itálica?

(c') Terceira (e principal) hipótese: o modelo teórico que melhor explica a perda do traço de quantidade das vogais latinas é, a priori, o gerativo ${ }^{2}$, no que se refere às mudanças ocorridas durante a aquisição da linguagem. O próprio Silva Neto (1957a) entreviu essa mudança aquisicional, mesmo antes de a teoria gerativa ganhar prestígio mundial. Entretanto, limitou-se a descrever brevemente como processos desse tipo ocorreriam, sem fazer maiores teorizações sobre o tema. Além disso, mesmo com o caráter inovador da proposta, não conseguiu desprender-se da explicação via substrato, apesar de criticá-la:

As línguas estão, pois, em perpétua mudança, embora só o repouso seja facilmente perceptível. A evolução explica-se, principalmente, pela descontinuidade da transmissão e pela própria constância do uso. Ao cabo de seu aprendizado, a criança fixa uma língua que não é exatamente a mesma das pessoas que Ihe serviram de modelo. Essa diferença, imperceptível numa geração, vai-se acumulando aos poucos (1957a: 15).

A influência do substrato é apenas uma das faces de problema bem mais complexo, de importância fundamental, que é o contacto e a interação linguística. O substrato, como salienta Jacobson, é um termo ambíguo; a realidade, já entrevista por Schuchardt, é que o choque de dois sistemas linguísticos no cérebro do mesmo indivíduo acarreta inovações, que depois se irradiam das células bilíngues (1957a: 140).

Como podemos ler na citação acima, Silva Neto já apresenta elementos que permitem contestar a demasiada importância dada à hipótese dos substratos, assim como a recente hipótese de que processos de pidginização e crioulização teriam sido os principais fatores responsáveis

\footnotetext{
${ }^{2}$ Utilizamos o termo "a priori", porque, como procuraremos demonstrar na seção "A Sociolinguística Paramétrica: uma reflexão ao nível do objeto teórico", o modelo que consideramos mais adequado é, na verdade, o que une o Gerativismo à Sociolinguística, ou seja, a Sociolinguística Paramétrica, cuja teorização inicial foi feita por Tarallo (1987).
} 
pela transformação do latim falado em português - e nas línguas românicas, como um todo. $E$, principalmente, ao afirmar que "a criança fixa uma língua que não é exatamente a mesma das pessoas que lhe serviram de modelo" e que "o choque de dois sistemas linguísticos no cérebro do mesmo indivíduo acarreta inovações, que depois se irradiam das células bilíngues", permitenos estabelecer uma clara relação entre tais afirmações e, respectivamente, a mudança paramétrica e a existência de uma faculdade da linguagem no cérebro humano, onde tais mudanças teriam lugar, abrindo-nos cabalmente o caminho para a aplicação dos desenvolvimentos recentes sobre a mudança aquisicional, no âmbito da teoria gerativa, ao processo de perda de quantidade vocálica em questão.

\section{A PERDA DA QUANTIDADE VOCÁLICA E SUAS IMPORTANTES REPERCUSSÕES}

A motivação para a escrita deste trabalho está na importância que a perda do traço de quantidade das vogais latinas teve para a formação da língua portuguesa - assim como das línguas românicas, de forma geral -, porque se trata de uma mudança linguística que serviu como fator desencadeador de uma série de outras mudanças nos demais subsistemas latinos, a saber, o morfológico e o sintático, provocando, assim, uma mudança no sistema como um todo, caracterizando a transformação do latim para o romance galego-português no Noroeste peninsular.

Castro (1991: 118), por exemplo, afirma, a esse respeito, que as alterações fonológicas geradas pela perda da distinção de quantidade "[...] tiveram enormes repercussões na morfologia e na sintaxe latinas, que reagiram em cadeia [...]" e procura expor sucintamente as etapas dessa cadeia, ao colocar que "[...] a perda de quantidade das desinências casuais levou à redução do número de casos; esta tornou mais difícil a identificação, por via flexional, das funções sintácticas, daí o recurso a outros processos, como a ordem de palavras".

Apesar de apontar outros fenômenos fonológicos como importantes para a perda da distinção morfossintática entre diferentes casos - a exemplo da apócope do $-m$, fonema que estava presente no final da desinência acusativa singular de todas as cinco declinações latinas, o que também contribuiu para a perda da distinção casual -, é à eliminação da distinção de quantidade, sofrida pelas vogais, que será atribuída a maior força motivadora desse processo. Vejamos um exemplo que ilustra o que estamos afirmando.

A palavra pertencente à primeira declinação latina, regină, nos casos nominativo e vocativo singular, tinha, como único fator de distinção entre esses dois casos e o caso ablativo singular, reginā, o traço fonológico da quantidade, já que a mencionada forma do ablativo em nada mais se diferenciava das formas nominativa e vocativa, a não ser através da diferença de quantidade presente na vogal final - $a$ da palavra, sendo a quantidade breve representada por -ă (acompanhada do sinal gráfico conhecido como bráquia [־]) e a quantidade longa representada por - $\bar{a}$ (acompanhada do sinal gráfico conhecido como mácron [־]). Desse modo, perdido o traço de quantidade - que, como já se pode perceber, era bastante sutil, e consequentemente fácil de ser eliminado -, esses três casos se neutralizavam, gerando a necessidade de que suas funções sintáticas começassem a ser indicadas por outros meios, como o uso de preposições e o enrijecimento da ordem das palavras na oração, em que cada posição viria a corresponder, a priori, a uma função sintática.

Se a apócope do - $m$ final, que mencionamos anteriormente, não fosse, também, um dos fenômenos fonológicos envolvidos nos processos de mudança do latim para o galego-português, talvez a perda da distinção de quantidade não gerasse, por si só, a necessidade tão acentuada do enrijecimento dos termos da oração, pois a manutenção do - $m$ final do acusativo singular permitiria, em algumas situações, a manutenção da ordem relativamente livre dos termos da oração latina, ao preservar a possibilidade de identificação da função sintática de alguns termos por dedução, como em:

(1) Regina ancillam clamat. 
Em que regina, apesar de não apresentar a marcação de quantidade breve em sua vogal final

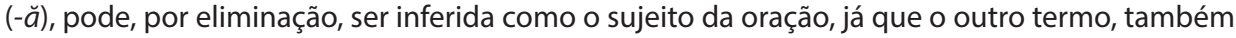
da primeira declinação, selecionado pelo verbo clamo, manteria a desinência de acusativo singular, permitindo, assim, a identificação do objeto direto, levando-nos a concluir que regina é o sujeito, mesmo sem a distinção de quantidade da vogal final. Porém, no momento em que o - $m$ final sofre apócope, passamos a ter:

\section{(2) Regina ancilla clamat.}

Nessa situação, em que nem mesmo o - $m$ do acusativo singular está presente para indicar a função sintática de um dos termos da oração, não é possível saber se a rainha chama a escrava ou se a escrava chama a rainha, já que nada mais indica, na própria morfologia da palavra, sua função sintática.

Nesse caso, o relacionamento da posição do termo da oração com a função sintática ganha uma importância, antes, pouco acentuada, já que, ao estabelecer a relação entre a primeira posição (pré-verbal) da oração e a função de sujeito e entre a última posição (pós-verbal) da oração e a função de objeto direto, passamos a ter um novo e eficaz parâmetro para identificar a função sintática de seus termos, como em:

(3) Regina clamat ancilla.

Será justamente essa a ordem que virá a caracterizar o romance galego-português, ou seja, a ordem Sujeito + Verbo + Objeto (SVO).

Entretanto, a apócope do - $m$ final é um fenômeno fonológico, e não uma mudança fonológica, já que o fonema / $\mathrm{m} /$ continuou a existir, sem modificação orgânica, enquanto a perda do traço de quantidade das vogais não foi apenas um fenômeno fonológico, mas também uma mudança fonológica, já que o ā longo e o ă breve se fundiram - desfazendo-se a distinção de quantidade do fonema -, enquanto o ĭ breve e o ē longo e o ŭ breve e o ō longo, além de se fundirem, resultaram, respectivamente, nos novos fonemas /e/ e /o/, já sem qualquer distinção de quantidade.

Percebemos, então, que a perda do traço de quantidade das vogais latinas trouxe problemas interpretativos que, como sempre acontece nas línguas naturais, em constante e imponderável mudança, foram resolvidos com novas soluções, como, por exemplo, o enrijecimento dos termos da oração e o uso de preposições para auxiliar na interpretação de suas funções sintáticas, inevitavelmente acarretando em transformações profundas que viriam a transformar o latim falado no galego-português e nos demais romances, precursores das línguas românicas atuais.

\section{A Sociolinguística Paramétrica: uma reflexão ao nível do objeto TEÓRICO}

Em 1987, Tarallo publica o texto Por uma sociolinguística românica "paramétrica": fonologia e sintaxe, em que procura demonstrar uma certa complementaridade entre a teoria sociolinguística e a teoria gerativa, com base em objetivos comuns, não apreensíveis de forma imediata e que, segundo ele, estão presentes nas duas vertentes de estudos linguísticos mencionadas.

Assim, no âmbito da teorização gerativista dos Princípios e Parâmetros, apresentada por Chomsky, pela primeira vez, na década de 1980, afirma que o maior aprofundamento da teorização dos parâmetros reflete-se na busca por respostas a duas questões levantadas por Borer (1983: 254), a saber: "[...] which component of the grammar will assume the burden of delimiting the universal principles so as to generate the wide variety of existing grammars?" e "What will determine the parametric range?", que teriam relação com três dos cinco problemas colocados por Weinreich, Labov e Herzog (1968/2006: 121-124) nos Fundamentos empíricos para uma teoria da mudança linguística, a saber: 
[i] O problema dos fatores condicionantes [na estrutura linguística ${ }^{3}$. Sugerimos que um possível objetivo para uma teoria da mudança é determinar o conjunto de mudanças possíveis e condições possíveis para a mudança [...].

[ii] O problema do encaixamento [na estrutura linguística]. Haverá pouca discordância entre os linguistas de que as mudanças linguísticas sob investigação devem ser vistas como encaixadas no sistema linguístico como um todo. O problema de oferecer fundamentos empíricos sólidos para a teoria da mudança traz à tona diversas questões sobre a natureza e a extensão deste encaixamento.

[iii] O problema da implementação [na estrutura linguística]. [...] Sugere-se que uma mudança linguística começa quando um dos muitos traços característicos da variação na fala se difunde através de um subgrupo específico da comunidade de fala. [...] Uma vez que a mudança linguística está encaixada na estrutura linguística, ela é gradualmente generalizada a outros elementos do sistema.

Como percebemos nas questões levantadas por Borer (1983), a gramática gerativa tem como preocupação a identificação e a descrição do condicionamento estrutural de princípios linguísticos existentes na faculdade da linguagem, presente em todos os seres humanos desde o nascimento (biologicamente presente, portanto), daí seu caráter geral, pois precederiam o momento da aquisição de uma língua humana em particular.

Logo em seguida, Borer refere-se aos parâmetros caracterizadores das línguas humanas, marcados durante o processo de aquisição da linguagem por uma criança, dentro dos condicionamentos estruturais biologicamente estabelecidos pelos princípios universais da faculdade da linguagem.

Em suma, percebemos a preocupação dos gerativistas em identificar e descrever os universais linguísticos, assim como os fatores particulares e caracterizadores das milhares de línguas humanas existentes no mundo, atualmente, ou entre sincronias diferentes, e sobrepostas ao longo do tempo, de uma língua específica, no que Tarallo identifica como variação inter-sistêmica, ou seja, a variação entre línguas distintas ou entre sistemas distintos que fazem parte do longo devir histórico de uma língua específica.

Já nas três citações de Weinreich, Labov e Herzog, que expusemos acima, também em consonância com as reflexões de Tarallo, percebemos a preocupação dos autores dos Fundamentos empíricos para uma teoria da mudança linguística em estabelecer a identificação e a descrição do condicionamento estrutural da variação e da mudança dentro de uma mesma língua - e não entre línguas distintas, como no gerativismo - no que Tarallo identifica como variação intra-sistêmica, ou seja, a variação no interior de um mesmo sistema linguístico.

É justamente neste momento que Tarallo aponta a relação de complementaridade entre os dois modelos: os conhecimentos hauridos, nos estudos sociolinguísticos, da variação intrasistêmica, poderiam ser de grande valia para os conhecimentos hauridos, nos estudos gerativistas, da variação inter-sistêmica. E nada é mais lógico: a descrição dos processos de variação e mudança, dentro de uma mesma língua, podem, sem dúvida, contribuir para a identificação de seus parâmetros (no sentido gerativista do termo), que, por sua vez, marcam sua particularidade, enquanto língua, diante de outras línguas - seja num viés sincrônico, comparando-se as diferenças paramétricas apresentadas entre as línguas existentes hoje, distribuídas geograficamente neste mesmo momento histórico; seja num viés diacrônico, comparando-se as diferenças paramétricas apresentadas nas sincronias sucessivas do passado para hoje, ao longo de momentos históricos diferentes, que precederam a configuração atual de uma língua específica. Vejamos o que diz, Tarallo (1987: 55):

Salientamos, acima, através do texto de Borer [...], a inovação do modelo sintático paramétrico através da incorporação de uma nova dimensão de análise: a variação linguística inter-sistêmica. Ressaltaremos e argumentaremos no presente ensaio que, apesar de a teoria da variação (e da mudança) linguística se ater quase que exclusivamente à variação intralinguística, uma leitura e análise criteriosa de dados translinguísticos e/ou diacrônicos, cujos resultados tenham sido obtidos a partir do exame de vários sistemas linguísticos via teoria da variação e da mudança (do grupo românico ocidental, por exemplo), podem produzir generalizações, menos "indutivas" e mais "dedutivas" e mais "ao sabor" dos princípios previstos em um modelo paramétrico de sintaxe.

\footnotetext{
${ }^{3} \mathrm{Na}$ comparação que estabelece, Tarallo exclui, propositadamente, a dimensão social dos três problemas dos Fundamentos empíricos para uma teoria da mudança linguística, no intuito de focalizar a relação, que pretende explicitar, na dimensão estrutural, já que é a privilegiada pelo gerativismo, a outra face da comparação.
} 
Dois anos depois, Tarallo e Kato (1989/2007), em Harmonia trans-sistêmica: variação intra- e inter-linguística, como o próprio título do artigo já o indica, deixam ainda mais claro o propósito da conciliação dos estudos de variação intralinguística, típicos da Sociolinguística, com os estudos de variação interlinguística, típicos do Gerativismo, ao afirmarem que buscam enveredar por um caminho distinto dos mencionados, ou seja:

[...] aquele que resgata a compatibilidade entre as propriedades paramétricas do modelo gerativo e as probabilidades do modelo variacionista, seja para provar seu espelhamento e reflexo, seja para realinhar um modelo em função do outro. Acreditamos, assim, num direcionamento mútuo entre a variação intra- e inter-linguística, enfim: na harmonia trans-sistêmica (1989/2007: 16-17).

Porém, apesar de exporem, de forma lógica e convincente, a proposta de harmonia transsistêmica - apresentando, inclusive, estudos variacionistas de Labov, em que variantes fonológicas têm suas características marcadas também de forma binária, com "no/yes", "fine/rough" e "1/2", de maneira muito semelhante ao "+/-" da marcação de parâmetros diferenciadores de línguas no Gerativismo -, limitam-se a isso (o que não é pouco, que fique claro), ou seja, a expor como estudos intra- e inter-sistêmicos podem ser complementares, sem avançar para possíveis complementaridades mais profundas, que podem ser entrevistas, mesmo, no nível dos objetos de estudo do Gerativismo e da Sociolinguística.

Tal tarefa, entretanto, será empreendida, ao menos de forma embrionária, poucos anos depois, em 1997, no livro Sistema, mudança e linguagem: um percurso na história da linguística moderna (neste artigo, utilizamos a edição brasileira de 2004), de Lucchesi, quando, ao ressaltar o paradoxo existente entre a concepção de língua invariante do Gerativismo e a realidade da manifestação concreta da língua, altamente heterogênea e ordenada, e que constitui a concepção de língua da Socioliguística, pergunta: "[...] como integrar a variabilidade inerente à manifestação concreta do fenômeno linguístico na concepção de objeto de estudo que o gerativismo propõe à linguística?".

Com esta importante questão lançada, esboça uma resposta que, a nosso ver, é bastante convincente, ao expor que as manifestações concretas da língua

[...] não refletem apenas as estruturas mentais e processos cerebrais que constituem a faculdade da linguagem, el[a]s refletem também e inexoravelmente os padrões linguísticos determinados pelo processo histórico e social de constituição da língua que cada indivíduo fala, ou seja, da língua, enquanto objeto cultural. Esses padrões determinados no processo sócio-histórico de constituição das línguas atuam em alguma medida sobre as estruturas da faculdade da linguagem, donde a variabilidade verificada em qualquer manifestação do fenômeno linguístico (Lucchesi 2004: 215-216).

O processo de formação das línguas crioulas, altamente condicionado por fatores sociais principalmente os de ordem demográfica e econômica - e já amplamente estudado nos dias atuais, é uma prova cabal de como a formação sócio-histórica de um povo atua fortemente sobre a faculdade da linguagem dos indivíduos que o compõem.

Desse modo, podemos concluir que mesmo a faculdade da linguagem - onde se localizam os princípios universais da linguagem humana e onde são fixados os parâmetros que diferenciam uma língua de outra - apresenta estruturas variáveis em seu interior. E nem poderia ser diferente, porque, se a manifestação concreta da linguagem é o resultado imediato de um processo cognitivo prévio, realizado em milésimos de segundo nas nossas estruturas cerebrais, como tentar sustentar a afirmação de que o processo cognitivo gerador é homogêneo e seu resultado imediato, heterogêneo? Em outras palavras, se é o cérebro quem gera, na faculdade da linguagem, as estruturas linguísticas que serão concretizadas como seu reflexo, através do aparelho fonador, e se essas estruturas concretizadas são heterogêneas, nada mais nítido do que concluir que foi assim que elas se estruturaram na faculdade da linguagem, antes de sua concretização fonética.

É claro que, no nível fonético, fatores extrínsecos ao processo cognitivo de estruturação da linguagem podem interferir em sua manifestação concreta, tornando-a mais heterogênea do que o processo cognitivo que a originou, a exemplo de pressões articulatórias que podem provocar um descompasso entre as coordenadas linguístico-cerebrais emitidas e a realização dessas coordenadas no aparelho fonador, como supressões e assimilações de fonemas e supressões de morfemas. 
Porém, no nível sintático, em que temos o estabelecimento das relações dos termos da oração, as pressões articulatórias não podem interferir em sua organização, já que a supressão de um fonema ou de um morfema não pode levar à troca ou inclusão de itens lexicais e gramaticais ou à mudança na ordem dos termos da oração. Ainda assim, no caso das estruturas relativas, as variações existem, como podemos constatar a seguir:

(4) Eu tenho uma amiga cujo marido se mudou para o Rio.

(5) Eu tenho uma amiga que o marido dela se mudou para o Rio.

Da mesma maneira, no caso da colocação dos clíticos, as variações também existem. Vejamos:

(6) Eu vi-o no cinema.

(7) Eu o vi no cinema 4 .

Como podemos notar, os exemplos de variação, expostos acima, representam variáveis sintáticas cujas variantes, por sua heterogeneidade de natureza estrutural, só podem ter sido originadas no momento de sua concepção cognitiva, já que é apenas nesse momento que as estruturações sintáticas se formam, e não no momento de sua articulação no aparelho fonador.

Outra questão, relacionada ao objeto de estudo do Gerativismo e ao da Sociolinguística, diz respeito à localização desse objeto no âmbito das duas teorias: os gerativistas afirmam que a língua se localiza na faculdade da linguagem de um indivíduo (e, consequentemente, em seu cérebro) e os sociolinguistas afirmam que a língua se localiza na comunidade de fala (e, consequentemente, na sociedade), como se estivessem tratando de loci distintos.

Fazendo uso do argumento de Coseriu (1974) - quando questionou Saussure por ter, este, afirmado que a língua se localiza no âmbito social, e não no individual -, colocamos, nós: do que é composta uma sociedade, senão de indivíduos? $?^{5}$ Isto nos leva a concluir que a única diferença entre o locus do Gerativismo e o locus da Sociolinguística está no foco que se dá a eles, pois a natureza desses loci, em si, é a mesma.

A esse respeito, é interessante fazer comparações entre trechos escritos em artigos e livros sobre a teoria gerativa e sobre a teoria sociolinguística, conforme o faremos a seguir:

[i] [Gerativismo] Para Chomsky, embora a língua-I seja um objeto interno ao indivíduo, uma comunidade que fala a mesma língua partilha o mesmo conhecimento linguístico, isto é, pode apresentar uma língua-I comum no componente nuclear (core grammar) de sua gramática (Kato 2002: 312, grifo do original);

[ii] [Sociolinguística] [...] embora seja evidente que o indivíduo opera com regras e categorias gramaticais, a Sociolinguística se preocupa essencialmente com a gramática geral da comunidade de fala, e não com o sistema específico de um ou outro indivíduo (Lehmkuhl Coelho et al 2015: 67).

Como podemos perceber claramente nos dois trechos citados acima, tanto os gerativistas quanto os sociolinguistas, ao tratarem da localização de seu objeto de estudo, não conseguem fugir da dimensão social nem da dimensão individual, presentes, respectivamente, nas duas afirmações. Isto porque os gerativistas, ao colherem dados linguísticos para tentar caracterizar os parâmetros da gramática internalizada por um indivíduo, sempre terão de recorrer a dados linguísticos de outros indivíduos da mesma comunidade de fala, assim como os sociolinguistas, ao colherem dados linguísticos para tentar caracterizar a gramática da comunidade de fala, sempre terão de começar por um indivíduo em particular.

\footnotetext{
${ }^{4}$ Os exemplos expostos foram retirados de Lehmkuhl Coelho et al (2015: 28), embora, no caso das estruturas relativas, os autores os tenham extraído dos estudos sociolinguísticos pioneiros que Tarallo fez a esse respeito, na década de 1980.

5 “O positivismo linguístico, por sua tendência para 'coisificar' as abstrações, chega, de fato, a considerar a 'língua' e a 'fala' como duas coisas distintas e, em vez de colocar a língua no falar, coloca a 'fala' nos indivíduos e a 'língua' na sociedade (ou pior, na 'massa'), como se os indivíduos fossem a-sociais e a sociedade fosse independente dos indivíduos e das suas relações interindividuais. Também Saussure, como já se assinalou, incorreu neste erro" (Coseriu 1979: 46, grifo do original).
} 
Ou seja, a sociedade está presente no indivíduo, ao condicioná-lo de variadas formas (inclusive no que se refere à língua que receberá como dados linguísticos primários de aquisição, durante sua infância), assim como o indivíduo, ao longo de sua vida, estará presente na sociedade, ajudando a criar e a consolidar suas forças condicionadoras (inclusive no que se refere à língua que, junto com outros membros de sua comunidade, disponibilizará em forma de dados linguísticos primários para a nova geração e que, assim como o indivíduo o fez um dia, adquirirá aquela língua).

Enfim, explanar sobre o indivíduo sempre nos leva a esbarrar no social, assim como explanar sobre o social sempre nos leva a esbarrar no indivíduo.

Desse modo, só se justifica uma separação entre indivíduo e sociedade por uma questão de metodologia, já que, a depender do foco de análise adotado - se individual, se social -, podemos ter acesso a resultados distintos (mas que serão, sempre, complementares e mutuamente elucidativos). Epistemologicamente, entretanto, afirmar que estar a língua localizada no indivíduo e estar a língua localizada na sociedade são dimensões diferentes é um raciocínio que não se sustenta.

\title{
3.1. Aquisição da linguagem
}

\begin{abstract}
A GU [...] é caracterizada como o estágio inicial da aquisição da linguagem pela criança. Ela corresponde, portanto, ao estado da cognição linguística humana anterior aos estímulos da língua-E do ambiente. Todavia, a dotação genética presente na GU não implica que todos os indivíduos humanos desenvolverão exatamente a mesma língua-I. Como veremos, os gerativistas assumem que a GU é composta por dois conjuntos de elementos. O primeiro deles são os Princípios universais, comuns a todas as línguas humanas, e o segundo são os Parâmetros particulares, que serão formatados conforme a experiência linguística dos indivíduos. Dessa forma, é a formatação dos Parâmetros da GU - aliada à aquisição das arbitrariedades do léxico de uma língua particular - o fator responsável pela diversidade linguística, por contraste à universalidade dos Princípios comuns a todos os idiomas (Kenedy 2013: 91).
\end{abstract}

Como podemos perceber, na citação acima, retirada do Curso básico de linguística gerativa (2013), de Kenedy, as crianças já nascem portadoras de um componente biolinguístico inato, comum à espécie humana e presente em suas estruturas cerebrais, que seria o responsável por determinar que as cerca de seis mil línguas do mundo apresentem características comuns como o fato de toda língua, em sua sintaxe, ter um Sujeito e, em seu sistema verbal, marcar o Tempo, o Modo e o Aspecto (não necessariamente dentro da morfologia verbal nem nessa ordem), por exemplo. Isso significa que tal componente biológico, para existir no cérebro humano, independe de fatores sociais, já que faz parte de nosso genoma.

Se é assim, então, por que não falamos, todos, uma mesma língua?

Como a citação também deixa claro, se, por um lado, tal componente biológico é o responsável pela conformação de um dos dois conjuntos de elementos componentes da GU, ou seja, os Princípios, que são universais, por outro, o segundo conjunto de elementos não seria dado geneticamente, mas "marcado" na GU como positivo ou negativo, em função da experiência social da criança, no âmbito da qual receberia um input linguístico fornecido pelas pessoas com quem interage, por meio da fala, em uma determinada comunidade humana. Tal conjunto de elementos é chamado de Parâmetros, que, ao contrário dos Princípios, não seriam universais, mas, sim, peculiares a cada língua, sendo, portanto, os responsáveis pela ampla variedade intersistêmica presente nas línguas humanas (essa fase, entretanto, desenvolver-se-ia com o auxílio dos Princípios inatos já presentes em suas estruturas cerebrais, motivo pelo qual uma criança consegue finalizar algo tão complexo, como a aquisição de sua primeira língua, ainda muito cedo, por volta dos cinco anos de idade).

Sendo assim, temos que a aquisição da linguagem é composta de duas grandes etapas: a primeira, já biologicamente suprida e estruturada em seu cérebro, não dependendo de estímulos externos, já que é um dote genético da espécie humana - é a etapa em que são delineados os Princípios da GU. A segunda, que começa a se desenrolar depois do nascimento da criança e que também se alocará em seu cérebro, mas dependente dos estímulos externos, que estarão presentes nos dados linguísticos primários (ou língua-E) dos falantes à sua volta, é a etapa em 
que são marcados os Parâmetros da GU, responsáveis por diferenciar as línguas humanas umas das outras (os Princípios e os Parâmetros marcados no cérebro de uma criança, juntos, compõem sua língua-I).

Desse modo, os gerativistas, depois de observarem o processo de aquisição da linguagem em crianças de diversas partes do mundo - o que vale dizer, crianças que adquiriram línguas diferentes -, perceberam que, em todos os casos não-patológicos, elas apresentaram estágios praticamente idênticos, com pequenas variações apenas em sua cronologia, mas sem variações quanto à natureza desses estágios - o que só reforça a hipótese de que a aquisição da linguagem realmente envolve um componente inato, comum à espécie humana. Tais estágios são os que apresentaremos a seguir, reproduzindo o quadro sintético elaborado por Grolla e Figueiredo Silva (2014: 69), no livro Para conhecer: aquisição da linguagem:

\begin{tabular}{|l|l|}
\hline \multicolumn{1}{|c|}{ Idade } & \multicolumn{1}{c|}{ Produção infantil } \\
\hline Primeiros meses & $\begin{array}{l}\text { - As crianças choram e emitem os primeiros sons; } \\
\text { - São capazes de distinguir línguas de grupos rítmicos diferentes. }\end{array}$ \\
\hline 6 meses & - As crianças balbuciam várias sílabas diferentes e repetidas. \\
\hline 10 meses & $\begin{array}{l}\text { - O balbucio infantil se restringe aos sons que ouvem; } \\
\text { - As crianças começam a emparelhar som e significado. }\end{array}$ \\
\hline 1 ano & $\begin{array}{l}\text { - Decresce a capacidade das crianças de discriminar sons de línguas diferentes } \\
\text { de sua língua materna; }\end{array}$ \\
\hline 1 ano e 6 meses & $\begin{array}{l}\text { - Produção das primeiras palavras, que valem por frases. } \\
\text { - Conhecem a produzir duas palavras com contorno frasal; }\end{array}$ \\
\hline Entre 2 e 3 anos & $\begin{array}{l}\text { - O vocabulário passa de } 400 \text { para 900 palavras; } \\
\text { - A fase das sobregeneralizações ('eu sabo', 'eu trazi'). }\end{array}$ \\
\hline Mais de 3 anos & $\begin{array}{l}\text { - Vocabulário já tem 1.200 palavras; } \\
\text { - As sentenças produzidas já possuem preposições, artigos e outras palavras } \\
\text { gramaticais; } \\
\text { - Estruturas complexas, como orações relativas e clivadas, são produzidas. }\end{array}$ \\
\hline
\end{tabular}

Quadro 2. Fases da aquisição da linguagem por uma criança

Vejamos o seguinte trecho do livro Linguagem e mente, de Chomsky (1968/2009: 315-316), cuja importância para o estudo da perda de quantidade das vogais latinas, que pretendemos demonstrar neste artigo, apontaremos na sequência, depois da citação:

A faculdade da linguagem é um dos componentes do que o co-fundador da teoria evolucionária moderna, Alfred Russel Wallace, chamava "natureza intelectual e moral do homem": as capacidades humanas para a imaginação criativa, a linguagem e outros modos de simbolismo, a matemática, a interpretação e o registro de fenômenos naturais, as práticas sociais complexas e que tais, um complexo de capacidades que parece ter-se cristalizado um tanto recentemente, talvez há um pouco mais de 50.000 anos atrás, entre um pequeno grupo reprodutivo de que todos descendemos - um complexo que coloca os seres humanos nitidamente à parte dos outros animais, inclusive dos outros hominídeos, a julgar pelo registro arqueológico.

Considerando-se que a faculdade da linguagem humana, onde se encontra a GU, se cristalizou há cerca de 50 mil anos e que, graças a essa faculdade, o processo de aquisição, em todos os seres humanos, segue etapas praticamente idênticas, podemos dizer, com alguma segurança, que, há cerca de 2 mil anos, quando se deu a perda do traço fonológico de quantidade das vogais latinas, as etapas de aquisição do latim, pelas quais passavam as crianças nascidas fora da região do Lácio, na Península Itálica e fora dela, eram, também, as mesmas pelas quais, hoje, comprovadamente, se sabe que uma criança passa ao longo do processo de aquisição de uma língua.

Desse modo, assim como as crianças de hoje, as crianças das regiões adjacentes a Roma como Pompeia - e à Península Itálica - como o Norte da África e a Península Ibérica - nasciam 
com sua GU estruturada em seu cérebro e composta pelos mesmos Princípios que, hoje, conhecemos como integrantes desse componente inato da linguagem humana - a exemplo da função de Sujeito e da marcação de Tempo, Modo e Aspecto na ação verbal, como já dissemos antes.

Isto parece pouco, mas, se considerarmos que já teríamos esclarecida a primeira das duas etapas do processo de aquisição - ou seja, a etapa dos Princípios - e parte da segunda etapa ou seja, a etapa de marcação dos Parâmetros -, graças às fases da aquisição da linguagem, por uma criança, descobertas e descritas no século XX, com base em estudos empíricos, percebemos que, na verdade, é algo merecedor de importância.

Consideremos, por exemplo, um jovem nascido em Pompeia, que, como sabemos, foi arrasada pela erupção do Vesúvio em 79 d.C. Além dos registros arqueológicos da cidade, hoje disponíveis a qualquer pessoa que tenha acesso à internet, é possível investigar, nos fósseis humanos que restaram - e que foram muitos - sua idade aproximada.

No estudo The pompeian wall inscriptions and the Latin language: a critical reappraisal, Kruschwitz e Halla-Aho (2007) afirmam que é possível depreender alguns dados sociais dos graffiti de Pompeia, a exemplo dos de conteúdo erótico. Segundo eles, é perfeitamente plausível deduzir que murais com escritos pornográficos tenham maior probabilidade de terem sido escritos por jovens, e não por anciãos.

Desse modo, se, no registro escrito em latim, feito num mural pompeiano, já houver a confusão entre "u" e "o" ou entre "i" e "e" - e, de acordo com Castro (1991), há -, isto é um sinal de que a perda quantitativa já vinha ocorrendo há algum tempo entre seus habitantes, na língua falada.

Indo além, se, através de estudos sobre os últimos momentos de Pompeia, a exemplo dos que se podem encontrar nos livros Os últimos dias de Pompeia, de Lytton (1961) e Vida, morte e ressurreição de Herculano e Pompeia, de Corti (1958), encontrarmos informações da idade aproximada de alguns dos corpos fossilizados - dentre os quais havia crianças, adultos e velhos, como é possível perceber visualmente -, será possível, tendo o ano de 79 d.C. como referência, datar com relativa precisão o momento da aquisição do latim, já sem o traço de quantidade de suas vogais.

Projetando-se, então, faixas etárias entre 0-20 anos, 20-40 anos, 40-60 anos e 60 anos ou mais, consideremos a faixa entre $20-40$ anos, já que são muitos os murais pompeianos de conteúdo erótico, fato que nos conduz a essa faixa etária.

Com base nas fases de aquisição da linguagem que conhecemos hoje, sabemos que, ao redor de 1 ano, a criança já ultrapassou as etapas de distinguir características rítmicas de línguas diferentes, de balbuciar sílabas repetidamente, de começar a relacionar som e significado e já estão na fase de produção das primeiras palavras com valor de frase.

Dito de outra maneira, uma criança de 1 ano já tem a capacidade de interpretar o componente fonológico de uma língua, com base nas amostras que lhe estão disponíveis na fonética aparente (Galves 1995). Além do que foi dito, reforçam-no as seguintes palavras de Chomsky (1993/2015: 155): “Variation must be determined by what is 'visible' to the child acquiring language, that is, by the PLD. It is not surprising, then, to find a degree of variation in the PF component, and in aspects of the lexicon [...]". E ainda: "A gramática de uma língua deve ser descoberta pela criança a partir dos dados a ela apresentados" (Chomsky 1968/2009: 151).

Assim, se o traço de quantidade das vogais, em 79 d.C., já começava a ser abandonado em Pompeia, isto significa que, no momento da aquisição da linguagem por parte dos autores das frases registradas, de forma escrita, nos graffiti, o traço de quantidade possivelmente não estava presente nos dados linguísticos primários que lhes foram fornecidos pelo componente fonético-fonológico dos adultos que estavam ao seu redor, pois, se o estivessem, a criança seria sensível a ele e o teria adquirido em seu componente fonológico.

Tomando, então, o limite máximo de 40 anos de idade como referência, considerando a faixa etária assumida entre 20-40 anos e considerando que o componente fonológico já começa a ser adquirido quando a criança está com 1 ano de idade, podemos considerar preliminarmente que, em 79 d.C., o traço de quantidade das vogais já estaria perdido (ou em vias de se perder) há, pelo menos, 39 anos, ou seja, em 40 d.C.

Indo ainda mais longe, considerando-se que, se, em 40 d.C., as crianças pompeianas já não estavam mais adquirindo o traço de quantidade por não terem mais acesso a ele nos dados 
linguísticos primários dos adultos da geração anterior - a exemplo de seus pais, nascidos, estes, portanto, em 25 ou 20 d.C., pelo menos -, podemos pressupor um recuo no tempo ainda maior para que tenha tido início o processo de perda da quantidade das vogais latinas.

Enfim, o fato de conhecermos, hoje, as etapas de aquisição da linguagem permite-nos fazer inferências que, em 1957, quando Silva Neto publicou sua História da língua portuguesa, não poderiam ser feitas tão facilmente e com maior segurança. Ainda assim, Silva Neto as fez e, ao fazê-las, conseguiu aproximar-se do modelo de aquisição que viria a ser proposto pelos gerativistas anos depois e, mesmo, de seu modelo de explicação da mudança linguística, calcado na mudança paramétrica ocorrida de geração para geração, no momento da aquisição.

Os estágios da aquisição da linguagem abordados até aqui e que, como vimos, podem servir de parâmetro (no sentido comum da palavra) para compreendermos como se deu a aquisição do latim no período Republicano e Imperial de Roma estão, por sua vez, dentro do chamado período crítico de aquisição da linguagem, assim chamado por ser aquele em que a faculdade da linguagem, localizada no cérebro humano, está mais aberta aos dados linguísticos primários de uma língua específica, sendo, por isso, “[...] um período em que a aquisição da primeira língua deve se efetivar, sob pena de não ser mais possível adquirir uma língua com a perfeição com que os seres humanos em geral o fazem [...]" (Grolla / Figueiredo Silva 2014: 60).

E aqui, mais uma vez, e para fechar este subitem, apontamos mais um aspecto teórico comum entre o Gerativismo e a Sociolinguística, concebido de maneira tão semelhante nas duas teorias, a ponto de parecerem ter sido escritos pelo mesmo autor, a não ser pela utilização de termos técnicos identificadores de uma e outra teoria, como "língua-I", marcando a filiação gerativista, e "mudança em tempo aparente", marcando a filiação sociolinguística. A ideia do período crítico, entretanto, seguido de uma estabilização da gramática, que será a mesma, no indivíduo, para o resto de sua vida, assim como o fato de serem as pequenas diferenças aquisicionais as que vão matizar a gramática dos pais em relação à gramática dos filhos, estão fortemente presentes nas duas vertentes, como demonstraremos com as citações abaixo - as duas primeiras, de gerativistas (incluindo o próprio Chomsky); a última, de sociolinguistas:

[i] [Gerativismo] A aquisição da linguagem será concluída e, assim, uma língua-I terá emergido na mente de uma pessoa, quando a GU tiver retirado do ambiente informações suficientes para a formatação da gramática de uma língua específica. Quando isso acontece, dizemos que o processo de aquisição atingiu o estágio estável. A partir do estágio estável, o conhecimento linguístico da pessoa já está constituído e apenas mudanças superficiais devem acontecer, tais como a aquisição de novos itens lexicais (Kenedy 2013: 96, grifo do original);

[ii] [Gerativismo] A gramática de uma língua deve ser descoberta pela criança a partir dos dados a ela apresentados. [...] Em suma, a língua é "reinventada" a cada vez que é aprendida, e o problema empírico a ser enfrentado pela teoria da aprendizagem é o de como pode ocorrer essa invenção da gramática (Chomsky 1968/2009: 151-152);

[iii] [Sociolinguística] A transmissão está diretamente implicada na aquisição da linguagem. Nesse sentido, estudos apontam para a seguinte condição geral: as crianças adquirem o vernáculo (isto é, a fala espontânea) diferentemente de seus pais e sofrem influência direta dos pares pré-adolescentes, provocando uma reorganização vernacular que dura até que se dê a estabilidade do sistema linguístico do indivíduo (mais ou menos na adolescência). Esse processo segue a mesma direção a cada geração. Nesse caso, é natural e esperado que os vernáculos de pais e filhos apresentem diferenças.

Segundo a hipótese "clássica" sobre a mudança linguística na sincronia, conhecida como mudança em tempo aparente, cada pessoa preserva durante a vida o sistema vernacular que foi adquirido durante seus primeiros anos de formação até a puberdade (de 5 a 15 anos, aproximadamente). Assim, na maturidade e mesmo quando enveIhecemos, em geral nossa fala reflete o vernáculo desses anos iniciais. Dessa forma, podemos perceber indícios de mudança linguística ao comparar uma geração a outra. Da observação sincrônica de faixas etárias diferentes, pode-se ver, por exemplo, quais as mudanças linguísticas que estão em curso (ou em progresso) (Lehmkuhl CoeIho et al 2015: 85-86, grifos do original).

Nada mais "mudança paramétrica" do que essa última citação da Sociolinguística e nada mais "mudança em tempo aparente" do que aquelas duas primeiras citações do Gerativismo. E não é para menos, já que, em última análise, ao tratarem do mesmo fenômeno, acabam por desenvolver, paralelamente, a mesma teorização. 


\subsection{Fonética e Fonologia}

Considerando-se que, neste trabalho, Gerativismo e Sociolinguística foram colocados sobre uma base epistemológica comum (depois das adaptações necessárias para isso, evidentemente) e que a Sociolinguística utiliza, em suas análises sobre a variação e a mudança, o aparato teórico da Fonética e Fonologia Estruturalistas, tal prática, já consagrada nos estudos sociolinguísticos há quase 50 anos, abre-nos a porta para que façamos o mesmo. Além disso, de acordo com Cristófaro Silva (1998/2015: 118), a fonologia estruturalista constitui "[...] a tentativa inicial de formalização da cadeia sonora da fala cuja terminologia e premissas são presentes (mesmo que de modo subjacente!) em modelos fonológicos subsequentes".

Por ser um aparato teórico já amplamente divulgado e conhecido, ater-nos-emos, aqui, apenas aos pontos que são importantes ao nosso artigo - diferentemente do item anterior, que exigiu reflexões mais profundas, já que se tratou de um momento que, necessariamente, teve de envolver um pouco de teorização. Desse modo, comecemos pela tradicional diferenciação entre Fonética e Fonologia, desenvolvida no âmbito do Círculo Linguístico de Praga, citando as seguintes palavras de Trubetzkoy (1939/1970: 12-13):

A côté de la définition de la phonétique comme science des sons de la parole, et de la phonologie comme science des sons de la langue, on en pourrait donner une autre selon laquelle la phonétique serait une étude purement phénoménologique des sons du langage, tandis que la phonologie serait une étude de la fonction linguistique de ces mèmes sons [...].

Como podemos perceber, por se tratar de uma definição calcada no Estruturalismo saussureano, a visão dicotômica entre língua e fala - que concebe a língua como sistêmica e homogênea e a fala como a-sistêmica e heterogênea - está bastante enraizada nesta separação entre fonética e fonologia. Entretanto, como já deixaram bastante claro os avanços da Sociolinguística, tal separação não se sustenta, no sentido de que tanto a língua quanto a fala são igualmente heterogêneas e sistêmicas, levando-nos a concluir que a fala é a manifestação concreta do sistema linguístico heterogêneo e ordenado, que está localizado na faculdade da linguagem humana, também heterogênea e ordenada, depois de marcados os parâmetros de uma língua particular dentro das possibilidades disponibilizadas pelos princípios universais e inatos da GU - e aqui já incluímos nossa visão epistemológica a respeito dessa questão.

Assim, a fonética seria o estudo da manifestação linguística no nível dos fones (sua unidade mínima de estudo), concretizada no aparelho fonador e apreensível na fala, enquanto a fonologia seria o estudo da manifestação linguística presente no cérebro humano, no nível dos fonemas (sua unidade mínima de estudo e o equivalente cognitivo-cerebral do fone) - portanto, num momento imediatamente prévio à concretização da fala. Desse modo, entre língua e fala, não há diferença que vá além do meio e do momento em que ocorrem: a língua, na cognição e antes da concretização articulatória; a fala, no aparelho fonador e depois da elaboração cognitiva. Afora isso, trata-se do mesmo fenômeno.

Pelo fato de os fonemas ocorrerem no cérebro humano, ainda no plano da cognição - e, por isso, indisponíveis para a observação direta -, sua observação só é possível de ocorrer de maneira indireta, através de sua depuração na massa sonora sistematizada dos fones - estes, sim, diretamente disponíveis, graças a sua concretização feita através do aparelho fonador. Através dos fones, portanto, chega-se aos fonemas.

No que se refere a este artigo, interessa-nos compreender como se dá a ocorrência dos fones e fonemas vocálicos, já que é a perda da quantidade das vogais latinas a mudança linguística que nos propomos a analisar.

Vejamos, então, como se concebe um fone ou segmento vocálico, do ponto de vista de sua manifestação concreta ou articulatória:

Na produção de um segmento vocálico, a passagem da corrente de ar não é interrompida na linha central e, portanto, não há obstrução ou fricção no trato vocal. Segmentos vocálicos são descritos levando-se em consideração os seguintes aspectos: posição da língua em termos de altura; posição da língua em termos anterior/ posterior; arredondamento ou não dos lábios (Cristófaro Silva 1998/2015: 66, grifo do original). 
A altura é a movimentação vertical que o corpo da língua faz durante a articulação de uma vogal. No latim, a língua assumia três posições de altura, correspondentes a distinções cognitivas: alta, média e baixa. No português, passou a assumir quatro posições de altura, correspondentes a novas distinções cognitivas: alta, média-alta, média-baixa e baixa.

A anterioridade/posterioridade é a movimentação horizontal que o corpo da língua faz durante a articulação de uma vogal, que varia em função da divisão da cavidade oral em três partes: anterior, próxima à saída da boca; central; e posterior, próxima ao véu palatino.

O arredondamento dos lábios refere-se ao fato de estarem estendidos ou arredondados durante a movimentação da língua nas dimensões vertical e horizontal (Cristófaro Silva 1998/2015: 68).

Desse modo, se quisermos, por exemplo, descrever os segmentos vocálicos [i], [a] e [u], de acordo com esses parâmetros, teríamos as seguintes descrições: [i]: alta anterior não arredondada; [a]: baixa central não arredondada; e [u]: alta posterior arredondada. As descrições fonéticas, seja de vogais, seja de consoantes, são sempre feitas com seus símbolos (disponíveis no International Phonetic Alphabet [IPA]) entre colchetes.

Os três parâmetros articulatórios citados compõem as articulações primárias das vogais. Porém, além das articulações primárias, que são as mais importantes, temos as articulações secundárias. É justamente dentre essas últimas que se encontra a quantidade ou duração, articulação que "[...] só pode ser medida comparativamente em relação a outros segmentos. Em outras palavras, a duração é uma medida relativa entre segmentos [...]" (Cristófaro Silva 1998/2015: 71).

A tonicidade da sílaba, como teremos oportunidade de observar na próxima seção, pode ter grande influência sobre a quantidade vocálica, vindo mesmo a condicioná-la, quando o traço de quantidade que distinguia cognitivamente as vogais se perde, como foi o caso do latim falado. Assim, o traço da quantidade continua ocorrendo, mas sem mais estabelecer distinção cognitiva (i.e. fonológica), já que tem como única razão de ser o fato de as vogais em sílaba tônica serem sempre pronunciadas com maior força e robustez, o que automaticamente as torna mais longas:

Se este for o caso na língua a ser descrita, pode-se assumir que a duração é causada pelo acento, e não em oposição a outras vogais do sistema daquela língua. Em algumas línguas, a duração é extremamente importante na produção dos segmentos vocálicos, como o inglês [e o latim], por exemplo. Note que em inglês as palavras têm significados diferentes se a vogal for longa ou breve: "to leave" sair [li:v] e "to live" viver [liv]. Em português, este não é o caso [devido à perda da distinção fonológica da quantidade, no latim falado], embora as vogais acentuadas sejam percebidas como mais longas em relação às vogais não acentuadas (Cristófaro Silva 1998/2015: 71).

Vejamos, agora, como se concebe um fonema, do ponto de vista de sua manifestação cognitiva: "[...] são os sons de uma língua que têm valor distintivo (servem para distinguir palavras). Sons que estejam em oposição [...] são caracterizados como unidades fonêmicas distintas e são denominados fonemas" (Cristófaro Silva 1998/2015: 126, grifo do original).

$\mathrm{Se}$, como vimos, um som, para que tenha status de fonema, deve distinguir cognitivamente uma palavra de outra, coloca-se, então, um problema prévio à identificação de um fonema: como saber se o som gera distinção de sentido? A resposta também é dada por Cristófaro Silva (1998/2015: 126, grifo do original): "O procedimento habitual de identificação de fonemas é buscar duas palavras com significados diferentes cuja cadeia sonora seja idêntica. As duas palavras constituem um par mínimo".

Esses pares mínimos, por sua vez, devem ser buscados na produção concreta da língua (ou seja, na fala), ao identificarmos Sons Foneticamente Semelhantes (SFS) que, no caso das vogais, são aqueles que se distinguem um do outro por apenas uma característica de sua articulação, a exemplo de [i] e [e], que são, ambos, anteriores e não arredondados, porém diferentes no que se refere à altura, já que um é alto e o outro é médio-alto, respectivamente. Como veremos, apenas essa pequena diferença em uma propriedade articulatória já é suficiente para que esses sons gerem oposição de sentido quando ocorrem na situação de Contraste em Ambiente Idêntico (CAl): p[i]ra/p[e]ra. Desse modo, se, no ambiente idêntico (p_ra), apenas a troca de uma vogal pela outra gera a oposição de sentido, como de fato ocorreu, isto significa que ambas têm tal capacidade e que, por isso, são consideradas fonemas (Cristófaro Silva 1998/2015). 
Ao se constatar que são fonemas, por gerarem distinção cognitiva, devem vir representadas por barras, quando nos referirmos a elas dentro do sistema fonológico de uma língua, ou seja, /i/ e /e/.

De acordo com o que dissemos linhas atrás, os fonemas devem ser identificados a partir de uma depuração na manifestação concreta da língua, a fala. Isto porque, na fala, podemos ter realizações parcialmente distintas para um mesmo fonema, sem que isso altere seu valor distintivo e caracterizador do sentido de uma palavra. Como, na fonologia, o que interessa é o valor distintivo, procura-se, então, identificar quais são as possíveis realizações parcialmente distintas de um mesmo valor fonológico, os alofones, escolhendo-se o mais recorrente para representar o fonema e simplificar a descrição fonológica. Por exemplo, a vogal alta anterior não arredondada, que grafamos como $i$, quando em posição tônica, realiza-se como [i]; quando em posição postônica final, como [l]; e quando em posição tônica seguida das consoantes nasais [m] e [n], como [î]. Porém, em todos os casos, mantém o mesmo valor distintivo da vogal alta anterior não arredondada, daí ser escolhida a realização mais recorrente dessa vogal para representar seu valor fonêmico, nesse caso, a realização [i], que passará a ter sua notação fonológica entre barras: /i/ (Cristófaro Silva 1998/2015).

No latim, além das características articulatórias primárias (altura, anterioridade-posterioridade e arredondamento ou não dos lábios), a característica articulatória secundária da quantidade, como já apontamos, produzia SFS com oposição fonológica, de modo que, no caso do fonema /i/, na situação de CAl, se a propriedade articulatória da quantidade da vogal fosse diferente no par mínimo estabelecido, o sentido da palavra mudaria, gerando oposição fonológica, como no exemplo pīlus (pelotão de soldados) / pǐlus (pelo, cabelo). Assim, concluímos que, no caso das vogais latinas, essa propriedade articulatória deve ser inclusa na descrição das vogais: /ī/: alta anterior não arredondada longa e /îl: alta anterior não arredondada breve.

Nesta seção, afirmamos que adotaríamos como base para as reflexões, contidas neste texto, a teorização de Tarallo (1987) e Tarallo e Kato (1989/2007), relativa à harmonização entre a variação intra-sistêmica, focalizada pela Sociolinguística, e a variação inter-sistêmica, focalizada pelo Gerativismo. Entretanto, como os autores limitaram suas teorizações à complementaridade que os referidos estudos intra- e inter-sistêmicos podem ter, sem entrar num debate relativo ao próprio objeto de estudo que, como tentamos defender, é compartilhado pelas duas (e nesse sentido, defendemos que prevalece a concepção de língua heterogênea e ordenada da Sociolinguística, porém localizada na faculdade da linguagem do cérebro humano, prevalecendo, assim, o locus defendido pelo Gerativismo), tivemos, também, de teorizar, para, assim, complementar a base que começou a ser construída por Tarallo e Kato e, com os principais pilares epistemológicos estabelecidos, podermos afirmar - sem que fosse uma afirmação vazia - que nossos pressupostos teóricos seriam os da Sociolinguística Paramétrica.

E, para concluir esta etapa, expusemos, com base em Cristófaro Silva (1998/2015), os postulados da fonética e da fonologia estruturalistas, já que são importantes para a "releitura" que propomos aqui.

\section{Estudos ANTERIORES SOBRE A PERDA DA QUANTIDADE VOCÁLICA}

Em 1928, Meillet, ao tratar da perda de quantidade das vogais latinas, no seu Esquisse d'une histoire de la langue latine, afirma que, ao se observar os versos hexâmetros de Claudius e de Ausone, ambos nascidos no século IV d.C., já se pode perceber uma tentativa vã de utilizar a métrica latina com base na quantidade das vogais, pois os autores acabam por confundir a característica da quantidade com a da intensidade silábica, que já tinha condicionado a característica da duração, englobando-a:

De ce que des différences de durée entre ā, ē, ī, ō, ū, d'une part, et ă, ĕ, ̆̆, ŏ, ŭ, de l'autre, ont cessé de caractériser en propre chacune de ces voyelles et de ce que, dans la mesure où il y a eu des différences de durée des voyelles, eles ont dépendu de la place de l'accent, il n'est pas resulte que ē long se soit confondu avec ĕ bref, ō long avec ŏ bref, etc. (Meillet 1928: 246). 
Entretanto, tal fenômeno, de acordo com o autor, foi consequência de outro, anterior, no nível articulatório, ou seja, as vogais de quantidade longa eram pronunciadas com a língua numa altura mais elevada em relação às vogais de quantidade breve, pronunciadas com a língua numa altura menos elevada. Por exemplo, o ē longo era pronunciado como [e] e o ĕ breve era pronunciado como $[\varepsilon]$, o que acabou por gerar um novo traço distintivo: o timbre. Com o passar do tempo e com o timbre já também atuando na distinção entre longas e breves, o traço de quantidade, à medida que se enfraquecia, acabava por transferir sua função distintiva para o timbre, fortalecendo-o ao ponto de vir a prevalecer sobre o traço de quantidade, que deixou de ser percebido como distintivo nas vogais átonas. Isto porque, como as vogais em sílaba tônica são, sempre, pronunciadas com maior clareza, o traço de quantidade persistiu, ainda por algum tempo, com valor distintivo nas vogais das sílabas tônicas. Daí a afirmação de Meillet de que, em sílabas acentuadas, a distinção quantitativa se mantinha, porém condicionada à tonicidade:

Longtemps avant la disparition des opposition quantitatives propres aux voyelles elles-mêmes, ces oppositions avaient entraîné des différences d'articulation, des différence de timbre. Quand ē et ě ont cessé d'avoir en propre des durées différentes, les deux voyelles sont demeurées distinctes par le timbre. [...] Les langues romanes ont donc hérité d'un système qui, sans oppositions propres de quantité, présentait des oppositions de $e$ fermé et de e relativement ouvert (on ne saurait naturellement dire en quelle mesure cet e était ouvert ni en quelle mesure intervenaient d'autres particularités de la prononciation), l'une représentant l'ancien ē long et l'autre l'ancien ĕ bref; et de même il y avait opposition de $o$ fermé et de $o$ ouvert, de $i$ fermé et de $i$ ouvert, de $u$ fermé et de $u$ ouvert, les notions de "fermé" et "d'ouvert" n'étant jamais que relatives. L'ā long et l'ă bref se sont confondus à ce qu'il semble (Meillet 1928: 246).

Em 1957(b), Silva Neto, na História do latim vulgar, apresenta uma visão ainda pouco refinada, se comparada à que apresenta na História da língua portuguesa (1957a), sobre o fenômeno da perda de quantidade das vogais latinas, atribuindo-o à influência do substrato osco e ao aprendizado, pelos romanos, do grego, sem descrever nem explicar esses processos, assim como ao confinamento da quantidade vocálica ao acento de intensidade. As considerações que faz referem-se à importância que identifica nas inscrições de Pompeia, principalmente no que concerne ao nível fonético/fonológico de análise linguística, assim como ao fato de serem textos populares e datáveis:

75 - Por três razões principais é de capital importância o estudo das inscrições pompeianas: trata-se de textos de verdadeiro cunho popular, são datáveis com certa precisão, e representam o latim aprendido e adotado por uma população que antes falava osco.

76 - Não deve causar surpresa o fato de serem mais nítidas do que quaisquer outras as diferenças fonéticas, pois os graffiti são textos breves, onde não há muita oportunidade para grandes variações sintáticas. Assim um estudo minucioso das inscrições pompeianas mostra-nos:

perda da oposição quantitativa, em favor da oposição de timbre;

predomínio do acento de intensidade (Silva Neto 1957b: 182);

[...]

107 - Do primeiro século d.C., em diante, a intensidade começa a prevalecer, o que, como é natural, se verifica mais visivelmente na língua falada, visto que os Romanos das classes superiores, avezados nos estudos gregos, sob a direção dos pedagogos, impregnados da cultura da Hélade, se deixariam influenciar pelo acento musical da língua deles.

108 - No $3^{\circ}$ séc. d.C., com os terríveis abalos que sofreu o Império, com a decadência, cada vez maior, da minoria que conquistara o mundo, o acento de intensidade logrou vitória completa. É provável que o fato de o latim ter sido adotado como língua comum por gentes cujo idioma era originariamente outro tivesse favorecido a perda da distinção quantitativa (Silva Neto 1957b: 210).

Em 1963, Väänänen, no Introducción al latín vulgar, fará observações semelhantes às de Meillet (1928), ao afirmar que o traço de quantidade das vogais latinas permanecia apenas em textos poéticos e oratórios, embora não ressalte a confusão entre quantidade e intensidade apontada pelo mestre francês nos textos de Claudius e Ausone:

En latín, toda vocal simple tenía dos duraciones, breve y larga: i i e ē ă ā ǒ ō ŭ ū, y la cantidad vocálica era un elemento con valor diferenciador (o fonológico); las oposiciones lěvis "ligero" : lèvis "liso", sŏlum "suelo" : sōlum 
"solo", věnit "viene" : vēnit "ha venido", Rōmă (nom.) : Rōmā (abl.), etc., eran observadas estrictamente en la métrica y en las cláusulas oratórias clásicas (Väänänen 1963/1968: 61-62).

$E$, no que concerne às vogais em sílaba tônica, refere-se já ao estágio do romance, quando, nem mesmo nessa posição, o traço de quantidade apresentava mais o valor distintivo de outrora, permanecendo, então, apenas a diferença de timbre como traço distintivo, momento em que expõe a ilustrativa comparação da vogal possuidora dos traços distintivos de quantidade e de timbre, com a bandeira possuidora dos traços distintivos da cor e das lacerações, facilitando sobremaneira a compreensão de como o traço da quantidade se perdeu, ao mesmo tempo em que cedia ao timbre essa função; e termina suas considerações, afirmando que essa mudança foi a mais importante na história do fonetismo latino:

En romance, por el contrario, las vocales acentuadas no se distinguían de ordinario más que por el timbre, que en este caso constituye una oposición fonológica: cf. en fr. dais : dé, j'irais : j'irai (distinción que cae en desuso), pomme : paume; en italiano, indotto "indocto": indọtto "inducido", colto "cogido": colto"culto", pęsca "melocotón" : pesca "pesca". En otros términos, la oposición cuantitativa, acompañada, sin duda, durante un período más o menos largo por diferencias de timbre, se ha ido resquebrajando y ha terminado por ceder su puesto a la oposición cualitativa. Desde ese momento, la pareja sŏlum : sōlum ha resultado sollu : sọlu (cf. it. solo o suolo"suelo": sọlo"solo"). Supongamos un cierto número de banderas de señales que se distinguen entre sí por su color, pero que terminan por decolorarse hasta el punto de no tener ya color distintivo. Sin embargo, continúan sirviendo, gracias a desgarrones que existían ya hace tiempo sin haber sido percebidos (antes de reponer el color), como signos distintivos. El "color de la bandera" es la duración vocálica; el "desgarrón" es el timbre.

La transformación del timbre en duración [sic: não seria o contrário?] como elemento diferenciador es el cambio más importante que se ha producido en el fonetismo del latín [...] (Väänänen 1963/1968: 61-62).

Em 1972, Câmara Jr., no seu História e estrutura da língua portuguesa, fará considerações mais detalhadas do que os três autores citados anteriormente, ao descrever, com precisão, o sistema vocálico latino, com base nos conhecidos parâmetros articulatórios da altura e da anterioridade/ posterioridade da língua, assim como do arredondamento dos lábios no momento da pronúncia de uma vogal, em seguida acrescentando que cada uma delas ainda possuía outra característica distintiva, a quantidade, que permitia a essas vogais funcionarem, cada uma, como duas, dobrando a funcionalidade do sistema vocálico latino:

O sistema vocálico latino consistia no chamado triângulo de vogais cardiais: uma vogal central (ou ligeiramente anterior) baixa, em que a língua fica praticamente em posição de repouso (/a/), duas anteriores, com um avanço em dois graus para a parte anterior da boca e uma concomitante elevação gradual, respectivamente média e alta (/e/, /i/), e duas outras posteriores, com um correspondente recuo e elevação gradual da língua, acompanhado de um arredondamento dos lábios (/o/, /u/). A realidade fonológica era, entretanto, mais complexa, porque cada uma dessas vogais se desdobrava em duas - uma longa, de prolação mais demorada, e outra breve, de prolação rápida. A quantidade fazia, assim, de cada vogal - baixa, anterior média, anterior alta, posterior arredondada média, posterior arredondada alta - um par opositivo de longa versus breve [...] (Câmara Jr. 1972/1975: 41-42).

Mais adiante, ressalta o fato de a quantidade permitir a distinção flexional em nomes e verbos, assim como a distinção lexical:

No latim clássico, a quantidade tinha função distintiva: na flexão nominal e verbal, distinguiam-se, por exemplo, as desinências - $\bar{a}$, de ablativo, e -ă, de nominativo, para um mesmo nome, e, entre palavras, havia oposições como - mālum "maçã" : mălum "mau", dǐco "consagro" : dīco "digo", cĕras "uma planta" (nom. sing.): cēras "cera" (ac. pl.), mōlǐs "massa" (gen. sing.) : mŏlīs "moinho" (dat. abl. pl.), sŭdis, uma espécie de pau: sūdis "seco" (dat. abl. pl.) (Câmara Jr. 1972/1975: 41-42).

Por fim, atribui ao acento tônico a perda do traço distintivo da quantidade, momento em que podemos perceber uma discordância em relação a Meillet e a Väänänen, porque estes autores, como vimos, atribuem a perda do traço de quantidade ao fato de as vogais longas serem pronunciadas com a altura da língua mais elevada em relação às breves correspondentes, sendo o condicionamento do acento tônico um estágio posterior, já que, em posição acentuada, tendemos a pronunciar os fonemas com maior clareza, o que inibe, inicialmente, inovações no que se refere à perda de mecanismos linguísticos. Além disso, faz a importante observação de que, entre o grau de altura mais baixo (/a/) e o grau de altura mais elevado (/i/ e /u/), passaram a existir dois novos graus de altura (e não apenas um, como antes, no latim), representado agora pelas vogais /e/ e / $/ \varepsilon /$, anteriores e que passaram a ter valor distintivo entre si, e /o/ e / /, posteriores e que passaram a ter valor distintivo entre si, ressaltando ainda a coincidência tímbrica de ĭ breve 
e ē longo, promovendo sua fusão fonêmica em /e/ e de ŭ breve e ō longo, promovendo sua fusão fonêmica em /o/, explicando, assim, os principais rearranjos que resultaram no sistema fonológico do galego-português e, posteriormente, do português:

Já observamos que a intensificação do acento destruiu esse delicado jogo quantitativo no latim vulgar. Ao mesmo tempo, as vogais passavam a ser condicionadas pela incidência ou não do acento e, quando átonas, pela sua posição antes ou depois do acento. Assim se eliminou a quantidade como traço vocálico distintivo e se estabeleceram três quadros diversos para as vogais, conforme tônicas, pretônicas ou átonas finais.

No quadro tônico, as dez vogais latinas evoluíram para um quadro triangular de sete vogais: houve confluências e diferenciações que modificaram todo o sistema de oposições latinas. O dado novo foi o aparecimento de dois graus de elevação da língua em posição intermediária entre a posição baixa (/a/) e alta (/i/, /u/). Com isso se criou uma oposição distintiva entre um /ę/ ou /ọ/ abertos, com pouca elevação da língua, e um /ẹ/ ou /ọ/ fechados, com maior elevação da língua. O grau médio aberto resultou de /e/ ou /o/ breves, respectivamente; o grau médio fechado foi a confluência das vogais médias longas e das altas breves. Assim, só /i/ e /u/ longos, perdendo a sua quantidade distintiva, continuaram como vogais altas (Câmara Jr. 1972/1975: 41-42).

Em 1980, Teyssier, na sua História da língua portuguesa, afirma, de forma bastante sintética - devido às limitações editoriais às quais a obra teve de submeter-se -, que o acento tônico e a perda de quantidade foram mudanças ocorridas no mundo romano como um todo, embora não explique como se deu a relação entre o acento e a quantidade, algo intensamente presente nos demais autores, com exceção de Silva Neto (1957b). E finaliza, afirmando que as diferenças de timbre das vogais, antes apenas fonéticas, ganharam valor fonológico no latim imperial.

Ressaltamos, entretanto, que, por mais que pese o caráter sintético da obra, ainda assim tem o mérito da clareza e da organização das ideias apresentadas, possibilitando-nos uma visão panorâmica da mudança linguística em questão:

Até o fim do período imperial, o latim falado no Oeste da Península Ibérica conhece as evoluções gerais do mundo romano:

A) O acento tônico - Generaliza-se um acento de intensidade, cuja posição é determinada de maneira automática. Quando nenhuma ação contrária entra em jogo, a acentuação permanece a mesma em galego-português e em português contemporâneo. [...].

B) As vogais: perda das oposições de quantidade - O latim clássico possuía cinco timbres vocálicos, havendo uma vogal breve e uma longa para cada timbre, ou seja, um total de dez fonemas. As breves eram sempre mais abertas que as longas correspondentes.

O latim imperial perdeu as oposições de quantidade, mas conservou as oposições de timbre resultantes dos variados graus de abertura (Teyssier 1980/2007: 8-9).

Em 1992, Barros Ferreira, em Vestígios do romance moçarábico em Portugal, ao tratar da transformação do latim, como um todo, sem focalizar em um nível linguístico, nos romances ibéricos, afirma que podem ter sido resultado de processos de pidginização e crioulização da língua de Roma. Entretanto, consideramos tal hipótese pouco provável, pois é quase consenso, entre os autores da Linguística Românica, a ideia de ter prevalecido o bilinguismo entre as línguas autóctones pré-romanas e o latim falado, e não a mudança de língua abrupta, com imediata socialização, entre os dominados, da língua do dominador romano, condição para que se formassem os pidgins e, consequentemente, os crioulos nesse processo de contato linguístico:

No latim do ocidente peninsular havia, sem dúvida alguma, essas duas faces: uma, veiculada, sobretudo, pelo uso eclesiástico e religioso, que procurava conservar inalteradas as suas características, para cumprir eficazmente a sua função unificadora, trans-linguística; e uma outra, de comunicação livre, que não tinha qualquer pretensão senão a de permitir uma inter-comunicação eficaz. Assim sendo, aparece como extremamente plausível o paralelismo que Versteegh estabelece entre o modo como o latim falado teria evoluído e aquilo que, já mais perto de nós, vemos acontecer quando nascem os pidgins e os crioulos ${ }^{6}$ (Barros Ferreira 1992: 218).

Algo bastante claro que podemos notar, após o cotejo das análises presentes em Meillet (1928), Silva Neto (1957b), Väänänen (1963/1968), Câmara Jr. (1972/1975) e Teyssier (1980/2007), é seu caráter convergente e carente de tentativas de incursão por explicações que considerem

\footnotetext{
${ }^{6}$ Mattos e Silva (2006), em O português arcaico: fonologia, morfologia e sintaxe, Fonte (2010), em Rumores da escrita, vestígios do passado: uma interpretação fonológica das vogais do português arcaico por meio da poesia medieval, e Hricsina (2013), em Evolução do sistema vocálico do latim clássico ao português moderno (tentativa da verificação in corpora), também expõem, muito criteriosamente, o processo de perda da quantidade das vogais latinas. Fazem-no, entretanto, com base nas análises de boa parte dos autores resenhados neste artigo (i.e. Silva Neto, Väänänen, Câmara Jr., Teyssier e Castro), motivo pelo qual não foram incluídos nesta seção.
} 
o fenômeno da perda de quantidade das vogais latinas tanto em sua dimensão cerebral - considerando-se o indivíduo biológico - quanto em sua dimensão social - considerando-se o indivíduo biológico como imerso entre seus semelhantes, compondo, assim, uma sociedade.

Castro (1991), cuja análise já foi exposta no início deste artigo, aproxima-se dos cinco autores citados. As exceções são [i] o próprio Silva Neto (1957a), ao relacionar, na História da língua portuguesa, a mudança em foco com o processo de aquisição da linguagem, de geração para geração, e que nos motivou a refletir sobre tal processo e a propor seu desenvolvimento em bases científicas atuais, conforme expusemos ao longo deste texto, principalmente na seção denominada "A Sociolinguística Paramétrica: uma reflexão ao nível do objeto teórico"; e [ii] Barros Ferreira (1992), ao considerar que os romances ibéricos podem ter sido resultado de processos de pidginização e crioulização do latim, em contato com as línguas autóctones pré-romanas.

Estão, portanto, todos os autores, analisados nesta seção, dentro dos três eixos explicativos da perda do traço de quantidade das vogais latinas, em sua trajetória diacrônica até o português, que afirmamos, no início deste artigo, serem os dominantes em trabalhos de Linguística Românica, ou seja: [i] a abordagem das influências de substrato, devidas a longos processos de bilinguismo no seio dos povos conquistados pelos romanos; [ii] a abordagem de explicação dessa mudança como parte de processos de pidginização e crioulização do latim, ao longo de séculos de sua imposição sobre esses povos; e [iii] a abordagem dessa mudança como ocorrida na aquisição do latim como segunda língua, pelos adultos subjugados nas conquistas romanas, sendo nativizada - e, consequentemente, implementada - pelas gerações seguintes, compostas pelos filhos desses adultos.

\section{Conclusão}

Neste trabalho, apresentamos, na "Introdução", uma breve descrição do que é o traço fonológico da quantidade vocálica, assim como o fato de este traço ter-se perdido na passagem do latim para o galego-português.

Além de expor posicionamentos anteriores aos nossos, como os de Silva Neto (1957a) e de Castro (1991), relativos à cronologia e à localização do fenômeno da perda da quantidade vocálica, assim como à maneira através da qual se processou essa perda, expusemos, outrossim, nossas hipóteses a esse respeito, começando pelas secundárias, afirmando que tal fenômeno pode ter começado a ocorrer ainda antes de Cristo, durante as Guerras Púnicas, no período republicano de Roma, e que sua origem pode ter-se dado não apenas no Norte da África e na Campânia romana, como tradicionalmente se afirma, mas, também, no que foi a província romana conhecida como Tarraconense, situada ao Norte e parte do Sudeste da Península Ibérica. Por se tratar das hipóteses secundárias, limitamo-nos a descrevê-las e justificá-las brevemente, mais com o intuito de estabelecer um recorte temporal e geográfico para este trabalho do que de desenvolvê-las efetivamente, como acreditamos que tenha ficado claro na leitura feita até aqui.

Após a exposição das hipóteses secundárias, partimos para a hipótese principal, relativa ao processo, em si, da perda da quantidade vocálica no latim, argumentando que sua compreensão adequada e precisa só será possível se adotarmos, como parâmetros para sua análise, os estabelecidos na teorização atual do gerativismo no que se refere ao processo de aquisição da linguagem por uma criança, assentando essa teorização, entretanto, na base epistemológica da Sociolinguística Paramétrica, que teve seus primeiros desenvolvimentos postulados por Tarallo (1987) e Tarallo e Kato (1989/2007), quando propuseram a harmonia trans-sistêmica entre os modelos gerativo e sociolinguístico.

Na seção "A perda da quantidade vocálica e suas importantes repercussões", tratamos brevemente da motivação da escrita deste trabalho, apresentando um exemplo que demonstra como essa mudança teve implicações na compreensão das orações latinas, provocando, por isso, reorganizações estruturais, traduzidas, principalmente, no enrijecimento da ordem dos termos da oração em SVO, que viria a ser uma das principais características da estrutura oracional do português.

Na seção "A Sociolinguística Paramétrica: uma reflexão ao nível do objeto teórico", partimos para o aprofundamento da teorização de Tarallo (1987) e Tarallo e Kato (1989/2007), estenden- 
do-a ao nível do objeto de estudo e a seu locus, procurando conciliar o que, através de um olhar superficial, pareceria inconciliável, mas que, através de um olhar reflexivo, analítico e despido de "rivalidades" teóricas, mostrou-se claramente possível de ser feito.

Estabelecidas as orientações epistemológicas que serviriam de "lente" para que "enxergássemos", de maneira menos turva, o processo da perda de quantidade das vogais latinas, partimos, na sub-seção "Aquisição da linguagem", para uma tentativa, ainda embrionária, de exemplificação do processo, utilizando como referência de análise um jovem hipotético, com idade entre 20 e 40 anos, nascido em Pompeia, na primeira metade do séc. I d.C., procurando delinear, em alguma medida, o contexto de aquisição da linguagem dentro do qual estaria imerso, levando em consideração o componente biológico da linguagem já presente em seu cérebro desde seu nascimento, quando temos a marcação dos Princípios universais das línguas humanas, assim como as fases de aquisição da linguagem vivenciadas ao longo de sua infância, que foram ultrapassadas depois de seu nascimento, quando temos a marcação dos Parâmetros caracterizadores das línguas humanas específicas. Além disso, procuramos, na sub-seção "Fonética e Fonologia", situar teoricamente o uso que fizemos de noções como fone, fonema e quantidade vocálica, utilizando-nos, principalmente, dos estudos feitos, nesta seara, por Cristófaro Silva (1998/2015).

Por fim, na seção "Estudos anteriores sobre a perda da quantidade vocálica", expusemos as considerações feitas por diversos autores que a abordaram, como Meillet (1928), Silva Neto (1957b), Väänänen (1963/1968), Câmara Jr. (1972/1975), Teyssier (1980/2007) e Barros Ferreira (1992), para demonstrar que, de certa forma, são redundantes em suas análises, ressaltando, desse modo, a importância da reanálise com base nos estudos atuais sobre a aquisição da linguagem, que, no início deste artigo, nos propusemos a colocar, pois, como se pôde constatar nas palavras dos referidos autores, a abordagem que considere o componente biológico inato, no momento em que começa a aquisição da linguagem, assim como as fases subsequentes dessa aquisição, ambos descritos pelo paradigma gerativista, não está, nelas, presente.

Assim, esperamos que este caminho, que ora propomos, para a compreensão de como se deu o processo da perda de quantidade vocálica do latim ao português, se mostre viável, o que só será possível de constatar em pesquisas mais avançadas nessa linha, já que, neste momento, tivemos como intenção apenas expor nossas reflexões iniciais sobre a questão. Fazemos, aqui, também, a incitação a outros pesquisadores que, porventura, estejam elaborando reflexões semelhantes, paralelamente a estas que acabam de ser apresentadas, para que publiquem seus trabalhos a esse respeito, no intuito de que possamos, além de aprender com as pesquisas uns dos outros, reforçar essa visão sobre o tema, que, a nosso ver, pode vir a se mostrar bastante produtiva e adequada.

\section{Agradecimentos}

Agradeço ao Conselho Editorial da Revista e aos pareceristas anônimos, pela leitura crítica e pelas sugestões que enriqueceram este trabalho. Agradeço, também, à Dra. Tânia Lobo, pela leitura da primeira versão deste texto. Os eventuais problemas que forem encontrados são de minha inteira responsabilidade.

\section{REFERÊNCIAS BIBLIOGRÁFICAS}

Barros Ferreira, Manuela (1992): "Vestígios do romance moçarábico em Portugal", Arqueologia Medieval 1, 217-228.

Borer, Hagit (1983): Parametric syntax. Case studies in Semitic and Romance Languages. Dordrecht: Foris Publications.

Câmara Jr., Joaquim Mattoso (1972/1975²): História e estrutura da língua portuguesa, $2^{\mathrm{a}}$ ed. Rio de Janeiro: Padrão.
Castro, Ivo (1991): Curso de história da língua portuguesa. Lisboa: Universidade Aberta.

Chomsky, Noam (1968/2009): Linguagem e mente. São Paulo: Editora UNESP.

Chomsky, Noam (1993/2015): The minimalist program, $20^{\text {th }}$ Anniversary Edition. Massachusetts: The MIT Press.

Coseriu, Eugênio (1979): Sincronia, diacronia e história. Rio de Janeiro: Presença. 
Cristófaro Silva, Thaïs (1998/2015): Fonética e fonologia do português: roteiro de estudos e guia de exercícios. São Paulo: Contexto.

Fonte, Juliana Simões (2010): Rumores da escrita, vestígios do passado: uma interpretação fonológica das vogais do português arcaico por meio da poesia medieval. São Paulo: Editora UNESP/ Cultura Acadêmica.

Galves, Charlotte (1995): "Princípios, parâmetros e aquisição da linguagem", Caderno de Estudos da Linguagem 29, 137-152.

Grolla, Elaine / Maria Cristina Figueiredo Silva (2014): Para conhecer: Aquisição da linguagem. São Paulo: Contexto.

Hricsina, Jan (2013): “Evolução do sistema vocálico do latim clássico ao português moderno (tentativa da verificação in corpora)", Études Romanes de Brno 34/2, 205-225.

Ilari, Rodolfo (1998): Introdução à linguística românica. São Paulo: Ática.

Kato, Mary (2002): "A evolução da noção de parâmetros", D.E.L.T.A. 18/2, 309-337.

Kenedy, Eduardo (2013): Curso básico de linguística gerativa. São Paulo: Contexto.

Kruschwitz, Peter / Hilla Halla-Aho (2007): "The pompeian wall inscriptions and the Latin language: a critical reapparisal", Arctos 41, 31-49.

Lehmkuhl Coelho et al. (2015): Para conhecer: Sociolinguística. São Paulo: Contexto.
Lucchesi, Dante (2004): Sistema, mudança e linguagem. São Paulo: Parábola.

Mattos e Silva, Rosa Virgínia (2006): O português arcaico: fonologia, morfologia e sintaxe. São Paulo: Contexto.

Meillet, Antoine (1928): Esquisse d'une Histoire de la langue latine. Paris: Librairie Hachette.

Silva Neto, Serafim da (1957a): História da língua portuguesa. Rio de Janeiro: Presença.

Silva Neto, Serafim da (1957b): História do latim vulgar. Rio de Janeiro: Ao Livro Técnico.

Tarallo, Fernando (1987): "Por uma sociolinguística românica 'paramétrica': fonologia e sintaxe", Ensaios de Linguística 13, 51-83.

Tarallo, Fernando / Mary Kato (1989/2007): "Harmonia trans-sistêmica: variação intra- e inter-linguística", Revista Diadorim 2, 13-42.

Teyssier, Paul (1980/2007): História da língua portuguesa, $3^{a}$ ed. São Paulo: Martins Fontes (tradução de Celso Cunha).

Trubetzkoy, Nikolai (1939/1970): Principes de phonologie. Paris: Librairie Klincksieck (tradução de J. Cantineau).

Väänänen, Veikko (1963/1968): Introducción al latín vulgar. Madrid: Gredos.

Weinreich, Uriel / William Labov / Marvin Herzog (1968/ 2006): Fundamentos empíricos para uma teoria da mudança linguística. São Paulo: Parábola. 